\title{
Effect of Some Natural Extracts and Mineral Fertilization Rates on Growth and Yield of Some Egyptian Cotton Varieties
}

Fadia S. A. Tolba*; Salah A. H. Allam **; El-Sayed M. H. Shokr**; Abd El-Based A. Hassan* and El-Saeed M. M. El-Gedwy**

${ }^{*}$ Cotton Research Institute, Agricultural Research Center, Giza, Egypt

***Agronomy Department, Faculty of Agriculture, Benha University, Egypt Corresponding author: alsaeed.algedwy@fagr.bu.edu.eg

\begin{abstract}
A field experiment was conducted at the Experimental Farm of Sakha Agricultural Research Station (Kafr El-Sheikh Governorate), Agricultural Research Center, Egypt, during two successive seasons of 2019 and 2020 to study the effect of foliar spray with natural extracts and mineral fertilization treatments, i.e., control (full dose of mineral fertilization rates with $60 \mathrm{~kg} \mathrm{~N}, 30 \mathrm{Kg} \mathrm{P}_{2} \mathrm{O}_{5}$ and $48 \mathrm{~kg} \mathrm{~K} 2 \mathrm{O} / \mathrm{fed}[\mathrm{A}], 75 \% \mathrm{~A}$ and foliar spray of compost tea, $75 \% \mathrm{~A}$ and foliar spray of algae extract, $75 \% \mathrm{~A}$ and foliar spray of compost tea with algae extracts, $50 \% \mathrm{~A}$ and foliar spray of compost tea, $50 \% \mathrm{~A}$ with foliar spray of algae extract and $50 \% \mathrm{~A}$ and foliar spray of compost tea with algae extracts on vegetative growth, yield and yield components of two Egyptian cotton varieties, i.e., Giza 94 and Giza 97. The experiments were laid out in Randomized Complete Block Design (RCBD) with four replicates. Results reveal that the superiority of the promising cotton variety of Giza 97 in No. of sympodial/plant, No. of fruiting sites/plant, No. of opened bolls/plant, No. of total bolls/plant, opened bolls \%, seed cotton yield/plant (g), lint cotton yield/plant (g), boll weight $(\mathrm{g})$, lint \%, seed cotton yield/fed (kentar) and lint cotton yield/fed (kentar) in addition to recorded the lowest bolls shedding \% in both seasons as compared to Giza 94 cotton variety. While, the maximum plant height $(\mathrm{cm})$, No. of monopodial/plant, bolls shedding \%, seed index (g) and lint index (g) were achieved by Giza 94 variety in both seasons. Cotton plants treated by $75 \%$ A and foliar spray of compost tea with algae extracts significantly gave the maximum plant height, No. of sympodial/plant, No. of fruiting sites/plant, No. of opened bolls/plant, No. of total bolls/plant, opened bolls \%, seed cotton yield/plant, lint cotton yield/plant, boll weight, seed index, lint $\%$, lint index, seed cotton yield/fed and lint cotton yield/fed, followed by $75 \%$ A with foliar spray of algae extract treatment, respectively in both seasons. Cotton plants treated with $100 \%$ mineral fertilizer treatment markedly gave the maximum bolls shedding \% also recorded the lowest No. of opened bolls/plant and opened bolls \% in both seasons. Growing Giza 97 variety treated by $75 \%$ A and foliar spray of compost tea with algae extracts treatment recorded the greatest No. of sympodial/plant, No. of fruiting sites/plant, No. of opened bolls/plant, No. of total bolls/plant, opened bolls $\%$, seed cotton yield/plant, lint cotton yield/plant, boll weight, lint $\%$, seed cotton yield/fed and lint cotton yield/fed during both seasons. Based on the previous results it could be concluded that, growing promising cotton variety of Giza 97 treated by $75 \%$ A along and foliar spray of compost tea with algae extracts treatment produced the maximum seed cotton yield and its related traits.
\end{abstract}

Keywords: Egyptian cotton varieties, compost tea extract, algae extract, mineral fertilization rates.

\section{Introduction}

Cotton is considered the main fiber crop in Egypt as well as the world. Egyptian statistics indicate decreasing cotton cultivated area from 851283 fed on 1991 to about 183000 fed on 2020 year, with decreasing percent of about $75.50 \%$ that lead to a decrease in cotton production from 5826000 kentars (one kentar $=157.5 \mathrm{~kg}$ of seed cotton) on 1991 to about 1573000 kentars on 2020 year, with decreasing percent by about $73.00 \%$ in 2020 year comparing with the year 1991 (The Egyptian Cotton Gazette, 2021).

One of the reasons of the decreasing cotton cultivated area is unfair prices to producers and better net profits from alternatives crops especially grains in the same time high costs of cotton inputs. In addition to the very high cost of hand picking and insufficient trained picking workers. The improvement of cotton relies mainly upon the Cotton Research Institute, who through a long process of breeding, maintenance, evaluation of fiber and yarn quality properties test arrives at new genotypes of superior quality to replace the old ageing ones. Consequently, strenuous efforts have been always directed towards improving its quality to maintain the worldwide reputation it has gained.

Differences among cotton varieties have been reported by many researchers they found that significant differences between cotton varieties in plant height $(\mathrm{cm})$, No. of monopodial/plant, No. of sympodial/plant and No. of fruiting sites/plant [Alitabar et al. (2012); Elayan et al. (2015) and Mahdy et al. (2017)], No. of opened bolls/plant, No. of un-opened bolls/plant, No. of total bolls/plant, opened bolls \% and bolls shedding \% [Abdallah and Mohamed (2013); Kumbhar et al. (2015) and Kassambara et al. (2019)], boll weight ( $\mathrm{g}$ ), seed index 
(g), lint $\%$ and lint index (g) [Wen et al. (2013); Jamro et al. (2016) and El-Gedwy et al. (2018)] as well as seed cotton yield/plant $(\mathrm{g})$, lint cotton yield/plant $(\mathrm{g})$, seed cotton yield/fed and lint cotton yield/fed [Elayan et al. (2014); Babu et al. (2015); Mahmoud et al. (2016) and Ahmed et al. (2020 a)].

In recent years, the world focused his attention to minimize environmental pollution and human health impacts, by reducing the use of synthetic fertilizers and chemicals in crops production Abd El-Aal (2012) and El-Boukhari et al. (2020). About 9,000 macro algae species are classified into three main groups depending on the pigmentation including; brown, green and red algae. Algae are used in improving the agriculture output Babu et al. (2015) and Eef et al. (2018). More than 15 million tons of algae are produced annually and used as bio-fertilizer in agriculture and also used human food, animal feed and raw material for industry Begum et al. (2018).

Algae extract application for different crops has a great importance due to it contains high levels of organic matter, macro elements $(\mathrm{Ca}, \mathrm{K}$ and $\mathrm{P})$, micro elements ( $\mathrm{Fe}, \mathrm{Cu}, \mathrm{Zn}, \mathrm{B}, \mathrm{Co}, \mathrm{Mo}, \mathrm{Mn}$ and $\mathrm{Ni}$ ), polysaccharides, antioxidants, pigments, hormones, aliginic, vitamins and amino acids in addition to rich in growth regulators such as auxins, cytokinin, betaines and gibberellins Eef et al. (2018) and ElBoukhari et al. (2020). Numerous studies have revealed a wide range of beneficial effects of algae extract on cotton growth, yield and yield components, such as better crop performance, yield and many more Gencsoylu (2016); Salama et al. (2018); Sultana et al. (2018) and Yanni et al. (2020).

Compost tea a term used interchangeably with (watery fermented compost extracts), (compost steepage), (organic tea) and (compost leachate) to define waterbased compost preparations. The term does not distinguish between the productions methods Scheuerell \& Mahaffee (2002) and Haas \& Défago (2005). Compost is comprised of a large and diverse community of humic acids and other chemical nutrients such as carbon and nitrogen that support healthy plant growth. Reviews of literature suggest compost tea may retain to varying degrees some of the same beneficial attributes of compost. Compost tea can be prepared in a shorter period of time and can be applied directly on to plant surface. However, effects of compost tea are short lived and frequent and repeat applications are required Zewail and Ahmed (2015); Abd El-Gayed et al. (2019); Ahmed et al. (2020 b) and Ahmed (2021) show that foliar application by compost tea increased cotton growth, yield and its components.

The main aim of the investigation was to study the response of some Egyptian cotton varieties to foliar application by algae extract, compost tea and mineral fertilization rates for reducing the use of synthetic fertilizers as well as improving vegetative growth, yield and yield components.

\section{Materials and Methods:}

A field experiment was conducted at the Experimental Farm of Sakha Agricultural Research Station (Kafr El-Sheikh Governorate), Agricultural Research Center, Egypt, during two successive seasons of 2019 and 2020 to study the effect of foliar spray with natural extracts and mineral fertilization rates on vegetative growth, yield and yield components of two Egyptian cotton varieties.

\section{Soil Analysis}

Soil texture of the experimental site was clay and $\mathrm{pH}$ of 8.0. Soil samples were taken at soil preparation to depth of $0-30 \mathrm{~cm}$ for chemical and physical properties analysis of the experimental soil were determined according to the standard procedures described by Rowell 1995 and represented in Table 1.

Table 1. Chemical and mechanical analysis of the experimental soil of the two growing seasons (2019 and 2020)

\begin{tabular}{lcc}
\hline Properties & \multicolumn{2}{c}{ Season } \\
\cline { 2 - 3 } & $\mathbf{2 0 1 9}$ & $\mathbf{2 0 1 9}$ \\
\hline Chemical analysis & 3.50 & 4.22 \\
E.C. & 8.92 & 8.78 \\
pH (1 :2.5) & 3.21 & 2.86 \\
Ca Co3 \% & 1.82 & 1.91 \\
O.M \% & 0.119 & 0.125 \\
N \% ( total) & 62.15 & 69.51 \\
Available N (ppm) & 0.065 & 0.079 \\
P \% ( total) & 11.32 & 14.15 \\
Available P (ppm) & 0.24 & 0.31 \\
K \% ( total) & 340.23 & 400.55 \\
Available K (ppm) & & \\
Sand \% & 23.42 & 19.70 \\
Silt \% & 31.32 & 33.58 \\
Clay \% & 45.26 & 46.72 \\
Texture grade & Clay & Clay \\
\hline
\end{tabular}

\section{Treatment Details and Experimental Design}

Each experiment included fourteen treatments, which were the combination of two Egyptian cotton varieties and seven foliar spray with natural extracts and mineral fertilization rates.

A. Egyptian cotton varieties

1) Giza 94.

2) Giza 97 promising cross [(G.89 × R.101) $\times$ G.86] $\times$ G.94 which released as 97 cotton variety in 6/2019 season.

The varieties seeds were obtained from Cotton Research Institute, Agricultural Research Center, Giza-, Egypt and its pedigree was shown in Table 2. 
Table 2. Type and pedigree of studied Egyptian cotton varieties

\begin{tabular}{ccc}
\hline Cotton variety & Type & Pedigree \\
\hline Giza 94 & long staple (over 1 $1 / 4-13 / 8$ inch) & S1229× G.86 \\
Giza 97 & long staple (over 1 $1 / 4-13 / 8$ inch) & {$[($ G.89 $\times$ R.101) $\times$ G.86 $] \times$ G.94 } \\
\hline
\end{tabular}

B. Natural extracts with mineral fertilization rates

1) Control (full dose of mineral fertilization rates with $60 \mathrm{~kg} \mathrm{~N}, 30 \mathrm{Kg} \mathrm{P}_{2} \mathrm{O}_{5}$ and $48 \mathrm{~kg} \mathrm{~K}_{2} \mathrm{O} /$ fed) recommended dose (A).

2) $75 \% \mathrm{~A}$ and foliar spray of compost tea (B).

3) $75 \% \mathrm{~A}$ and foliar spray of algae extract (C).

4) $75 \% \mathrm{~A}$ and foliar spray of compost tea with algae extracts (D).

5) $50 \% \mathrm{~A}$ and foliar spray of compost tea (E).

6) $50 \% \mathrm{~A}$ and foliar spray of algae extract $(\mathrm{F})$.

7) $50 \% \mathrm{~A}$ and foliar spray of compost tea with algae extracts $(\mathrm{G})$.

Phosphorous fertilizer was applied at a rate of $30.0 \mathrm{~kg} \mathrm{P} \mathrm{P}_{2} \mathrm{O}_{5} / \mathrm{fed}$ in form of calcium super phosphate $\left(12.5 \% \mathrm{P}_{2} \mathrm{O}_{5}\right)$ after ridging and before cotton sowing in each season. Nitrogen fertilizer was applied at a rate of $60 \mathrm{~kg} \mathrm{~N} / \mathrm{fed}$ as ammonium nitrate $(33.5 \% \mathrm{~N})$ and divided into two equal parts and applied side dressed before first and second irrigations in each season. Potassium fertilizer was applied in form of potassium sulphate $\left(48 \% \mathrm{~K}_{2} \mathrm{O}\right)$ at a rate of $48 \mathrm{~kg}$ $\mathrm{K}_{2} \mathrm{O} / \mathrm{fed}$ in one dose before the second irrigation in each season (full dose as recommended by Ministry of Agriculture for control), other treatments of mineral fertilization rates were done by the same method using above mentioned rates.

Algae extract product imported by Techno Green Company Group, Cairo, Egypt. Algae extract contains minerals as ( $\mathrm{Fe}, \mathrm{Zn}, \mathrm{Cu}, \mathrm{Mn}$ and $\mathrm{Mo}$ ), vitamins, enzymes, amino acids, sugars and plant hormones (auxins, cytokinins and gibberellins) were used. The recommended value of Algae extract was one L/fed in each spraying. Chemical analyses of algae extract are shown in Table 3 .

Table 3. Chemical analysis of algae extract

\begin{tabular}{lclc}
\hline \multicolumn{1}{c}{ Characteristics } & $\begin{array}{c}\text { Value } \\
(\boldsymbol{\%})\end{array}$ & Characteristics & $\begin{array}{c}\text { Value } \\
(\boldsymbol{\%})\end{array}$ \\
\hline Oligosaccharide & 3.0 & Pepsin & 0.02 \\
Algnic acid & 5.0 & Potassium oxide & 12.0 \\
Phytin & 0.003 & Phosphorus oxide & 0.5 \\
Menthol & 0.001 & $\mathbf{N}$ & 1.0 \\
Cytokinine & 0.001 & $\mathbf{M n}$ & 0.1 \\
Indol acetic acid & 0.0002 & $\mathbf{F e}$ & 0.2 \\
\hline
\end{tabular}

The compost tea was extract from compost made from rice straw and cattle dung which, had been composted in aerobic heap for three months. To prepare enriched complete compost quality, ten $\mathrm{kg}$ of mature compost immersed in appropriate volume of water for 7 days to produce the extract. The recommended value of compost tea extract was 20
$\mathrm{L} /$ fed in each spraying. The analysis of compost tea is shown in Table 4.

Algae extract and compost tea were repeated three times as foliar spray; the first one was at the beginning of flowering at 65 days after sowing and repeated with 21 days intervals, the spray solution volume was $400 \mathrm{~L} / \mathrm{fed}$ using a hand operated compressed air. The application was carried out between 09:00 and 11:00 a.m.

Table 4. Nutrient contents of the extracted compost tea

\begin{tabular}{lc}
\hline Character & Concentration \\
\hline Ammonic nitrogen (mg/L) & 20 \\
Nitrate nitrogen (mg/L) & 35 \\
Total nitrogen (mg/L) & 120 \\
Total Phosphorous (mg/L) & 60 \\
Total Potassium (mg/L) & 50 \\
*COD (mg/L) & 980 \\
*BOD (mg/L) & 435 \\
pH (1:10) & 8.04 \\
\hline Where, COD: chemical oxygen demand and BOD: biochemical \\
oxygen demand
\end{tabular}

The preceding winter crop in the two seasons was Egyptian clover (Trifolium alexandrinum L.). Experiments were planted on $7^{\text {th }}$ and $1^{\text {st }}$ of May in first season (2019) and second season (2020), respectively. The plot area was $10.5 \mathrm{~m}^{2}$ and contained five ridges of $3.5 \mathrm{~m}$ long and $60 \mathrm{~cm}$ apart. Cotton plants was done by the local method of dibbling 5 to 7 seeds in each hill by hand with distance between hills was $30 \mathrm{~cm}$ apart and after 35 days of sowing thinning was carried out in order to maintain better two seedlings/hill (46667 cotton plants/fed). The fourteen previous treatments were arranged in Randomized Complete Block Design (RCBD) with four replicates. Pest and weed management were conducted as needed during the growing season, according to local practice performed at the experimental station. The first irrigation was applied after 21 day from sowing, while the other irrigations were given at 15-day interval. Hand hoeing was carried out three times during the season before the first, second and third irrigations, respectively. All recommended cultural practices for growing cotton according to Agricultural Research Center recommendation were done properly.

\section{Sampling and Data Collecting}

At harvest, ten guarded cotton plants were taken randomly from each sub-plot to determine the following characteristics. 
1) Plant height $(\mathrm{cm})$.

2) Number of monopodial/plant.

3) Number of sympodial/plant.

4) Number of fruiting sites/plant. Since flower counts were taken daily during the flowering period, it was possible to calculate the total number of fruiting sites produced/plant.

5) Number of opened bolls/plant. It was calculated by counting the opened bolls/plant on the above the representative plants before the first and second picking.

6) Number of un-opened bolls/plant. It was calculated by counting the un-opened bolls/plant on the above the representative plants before the first and second picking.

7) Number of total bolls/plant. It was calculated by counting the total bolls/plant on the above the representative plants before the first and second picking, it was calculated from the following formula were used:

Total No. of bolls $/$ plant $=$ (No. of open bolls $/$ plant $)+($ No. of Un - open bolls $/$ plant $)$

8) Opened bolls percentage. It was calculated from the following formula:

Open bolls $(\%)=\frac{\text { No. of open bolls/plant }}{\text { No. of total bolls/plant }} x \mathbf{1 0 0}$.

9) Bolls shedding percentage. It was calculated from the following equation:

Bolls shedding $\%=\frac{\text { (No. of fruiting sites } / \text { plant }- \text { Total No. of bolls } / \text { plant) }}{\text { No. of fruiting sites/plant }} \times 100$

10) Seed cotton yield/plant (g). It was estimate from the above ten representative plants.

11)Lint cotton yield/plant (g). It was estimate from the above ten representative plants.

12)Boll weight $(\mathrm{g})$. It was calculated from the following formula:

$$
\text { Boll weight }(\mathbf{g})=\frac{\text { Seed cotton yield } / \text { plant }(g)}{\text { No.of open bolls/plant }} \text {. }
$$

13) Seed index (g). It was estimated from the average of 100-seed weight $(\mathrm{g})$ was taken at random after ginning.

14)Lint percentage. It was calculated from the following equation:

$$
\text { Lint } \%=\frac{\text { Lint cotton yield } / \text { plant }(\mathrm{g})}{\text { Seed cotton yield/plant }(\mathrm{g})} \times 100 .
$$

15) Lint index (g). It was calculated from the following equation:

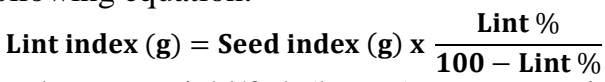

16) Seed cotton yield/fed (kentar): It was estimated and transformed to kentar/fed (one kentar $=157.5$ $\mathrm{kg}$ ), the seed cotton yield was picked twice in the two seasons, in picking from whole plants of plot were selected to be picked in order to avoid border effect.

17) Lint cotton yield/fed (kentar): It was estimated and transformed to kentar/fed (one kentar $=50$ $\mathrm{kg}$ ), it was calculated from the following equation:

Lint cotton yield $/$ fed $($ kentar $)=\frac{\text { Seed cotton yield } / \text { fed }(\text { kentar }) \times 157.5 \times \text { Lint } \%}{50 \times 100}$

\section{Statistical analysis:}

The analysis of variance was carried out according to the procedure described by Gomez and
Gomez (1984). Data were statistically analyzed according to using the MSTAT-C Statistical Software Package (Freed, 1991). Where the F-test showed significant differences among mean of treatments, the least significant difference (L.S.D.) test at 0.05 level was used to compare between means.

\section{Results and Discussion:}

\section{Performance of Egyptian cotton varieties}

Results presented in Table 5 show that almost cotton growth, yield and its related traits under study were differed significantly among the two Egyptian cotton verities (Giza 94 and Giza 97) in the both seasons. While, mean values in No. of un-opened bolls/plant in the both seasons, bolls shedding (\%) and seed index $(\mathrm{g})$ in the second seasons were not significantly affected by Egyptian cotton varieties under study.

Results reveal that the superiority of Giza 97 variety in No. of sympodial/plant (14.05 and 15.99), No. of fruiting sites/plant (40.56 and 45.24), No. of opened bolls/plant (18.55 and 19.62), No. of total bolls/plant (29.07 and 30.81), opened bolls percentage (63.70 and $63.50 \%)$, seed cotton yield/plant (62.78 and $69.76 \mathrm{~g})$, lint cotton yield/plant (25.14 and $27.50 \mathrm{~g})$, boll weight (3.369 and $3.530 \mathrm{~g}$ ), lint percentage (39.91 and $39.22 \%$ ), seed cotton yield/fed (10.76 and 11.95 kentar) and lint cotton yield/fed (13.57 and 14.83 kentar) in addition to recording the lowest bolls shedding percentage (27.98 and $31.79 \%$ ) in two seasons, respectively. The excess ratios between the promising cotton variety of Giza 97 over Giza 94 variety was 14.23 and $19.24 \%$ for No. of sympodial/plant; 11.25 and $16.63 \%$ for No. of fruiting sites/plant; 25.17 and $20.59 \%$ for No. of opened bolls/plant; 19.38 and $18.55 \%$ for No. of total bolls/plant; 5.08 and $1.83 \%$ for opened bolls percentage; 38.68 and $35.46 \%$ for seed cotton yield/plant; 44.40 and $41.32 \%$ for lint cotton yield/plant; 10.86 and $11.96 \%$ for boll weight; 4.15 and $4.14 \%$ for lint percentage; 24.68 and 21.94 $\%$ for seed cotton yield/fed in addition to 29.86 and $27.19 \%$ for lint cotton yield/fed, in first and second seasons, respectively.

The maximum plant height (150.33 and 155.25 $\mathrm{cm}$ ), No. of monopodial/plant (2.913 and 3.079), bolls shedding percentage (33.18 and $32.97 \%$ ), seed index (11.54 and $11.69 \mathrm{~g}$ ) and lint index (7.181 and $7.072 \mathrm{~g})$ were achieved by Giza 94 variety during both seasons, respectively. The superiority ratios between Giza 94 variety and Giza 97 variety was 8.93 and $10.92 \%$ for plant height; 43.71 and $33.81 \%$ for No. of monopodial/plant; 18.58 and $3.71 \%$ for bolls shedding percentage; 15.28 and $13.94 \%$ for seed index in addition to 7.79 and $6.60 \%$ for lint index in both seasons, respectively.

These differences in cotton yield and its related traits may be due to the genetic differences between cotton varieties under study (Giza 94 and Giza 97). 
As well as, It could be concluded that Giza 97 variety surpassed Giza 94 variety in cotton and lint yields/fed may be due to more likely attributed to the increases in No. of sympodial/plant, No. of fruiting sites/plant, No. of opened bolls/plant, No. of total bolls/plant, opened bolls percentage, seed cotton yield/plant $(\mathrm{g})$, lint cotton yield/plant $(\mathrm{g})$, boll weight $(\mathrm{g})$ and lint percentage in addition to the decrease in bolls shedding percentage. These results in good accordance with those reported by Alitabar et al. (2012); Abdallah and Mohamed (2013); Wen et al. (2013); Elayan et al. (2014); Babu et al. (2015); Elayan et al. (2015); Kumbhar et al. (2015); Jamro et al. (2016); Mahmoud et al. (2016); Mahdy et al. (2017); El-Gedwy et al. (2018); Kassambara et al. (2019) and Ahmed et al. (2020 a) show that varieties markedly varied for cotton yield and its related traits.

Table 5. Mean values of vegetative growth, yield and yield components of Egyptian cotton varieties during 2019 and 2020 seasons

\begin{tabular}{|c|c|c|c|c|c|c|}
\hline \multirow{3}{*}{ Trait } & \multicolumn{6}{|c|}{ Cotton variety } \\
\hline & Giza 94 & Giza 97 & $\begin{array}{l}\text { L.S.D. } \\
\text { at } 5 \%\end{array}$ & Giza 94 & Giza 12 & $\begin{array}{l}\text { L.S.D. } \\
\text { at } 5 \%\end{array}$ \\
\hline & \multicolumn{3}{|c|}{2019} & \multicolumn{3}{|c|}{2020} \\
\hline Plant height (cm) & 150.33 & 138.01 & 3.08 & 155.25 & 139.96 & 3.54 \\
\hline No. of monopodial/plant & 2.913 & 2.027 & 0.078 & 3.079 & 2.301 & 0.104 \\
\hline No. of sympodial/plant & 12.30 & 14.05 & 0.24 & 13.41 & 15.99 & 0.27 \\
\hline No. of fruiting sites/plant & 36.46 & 40.56 & 1.54 & 38.79 & 45.24 & 1.76 \\
\hline No. of opened bolls/plant & 14.82 & 18.55 & 0.76 & 16.27 & 19.62 & 0.84 \\
\hline No. of un-opened bolls/plant & 9.54 & 10.52 & N.S. & 9.72 & 11.19 & N.S. \\
\hline No. of total bolls/plant & 24.35 & 29.07 & 1.13 & 25.99 & 30.81 & 1.25 \\
\hline Opened bolls percentage (\%) & 60.62 & 63.70 & 0.90 & 62.36 & 63.50 & N.S. \\
\hline Bolls shedding percentage $(\%)$ & 33.18 & 27.98 & 1.02 & 32.97 & 31.79 & N.S. \\
\hline Seed cotton yield/plant (g) & 45.27 & 62.78 & 2.38 & 51.50 & 69.76 & 2.65 \\
\hline Lint cotton yield/plant (g) & 17.41 & 25.14 & 0.98 & 19.46 & 27.50 & 1.13 \\
\hline Boll weight (g) & 3.039 & 3.369 & 0.054 & 3.153 & 3.530 & 0.061 \\
\hline Seed index $(g)$ & 11.54 & 10.01 & 0.18 & 11.69 & 10.26 & 0.20 \\
\hline Lint percentage $(\%)$ & 38.32 & 39.91 & 0.18 & 37.66 & 39.22 & 0.22 \\
\hline Lint index (g) & 7.181 & 6.662 & 0.066 & 7.072 & 6.634 & 0.072 \\
\hline Seed cotton yield/fed (kentar) & 8.63 & 10.76 & 0.55 & 9.80 & 11.95 & 0.63 \\
\hline Lint cotton yield/fed (kentar) & 10.45 & 13.57 & 0.72 & 11.66 & 14.83 & 0.80 \\
\hline
\end{tabular}

Effect of natural extracts with mineral fertilization rates

Results in Table 6 indicate that all growth, yield and its related traits of Egyptian cotton were significantly influenced with application of seven studied natural extracts with mineral fertilization rates except No. of monopodial/plant, No. of unopened bolls/plant, bolls shedding percentage and seed index were not significantly affected in 2019 and 2020 seasons.

Cotton plants treated by $75 \% \mathrm{~A}$ and foliar spray of compost tea with algae extracts significantly produced the maximum mean values of plant height (151.09 and $155.85 \mathrm{~cm})$, No. of sympodial/plant (15.95 and 17.99), No. of fruiting sites/plant (43.57 and 47.55), No. of opened bolls/plant (20.27 and
22.10), No. of total bolls/plant (30.19 and 32.61), opened bolls percentage (67.14 and $67.75 \%)$, seed cotton yield/plant (70.10 and $80.28 \mathrm{~g})$, lint cotton yield/plant (28.40 and $32.14 \mathrm{~g}$ ), boll weight $(3.440$ and $3.612 \mathrm{~g}$ ), lint percentage (40.39 and $39.88 \%$ ), lint index (7.548 and $7.562 \mathrm{~g})$, seed cotton yield/fed (12.57 and 14.38 kentar) in addition to lint cotton yield/fed (16.02 and 18.11 kentar) in 2019 and 2020 seasons respectively, followed by $75 \%$ A with foliar spray of algae extract treatment. On the other hand, the lowest mean values of plant height (138.80 and $139.57 \mathrm{~cm})$, No. of sympodial/plant (11.06 and 12.28), No. of fruiting sites/plant (33.43 and 36.33), No. of total bolls/plant (23.96 and 25.25), seed cotton yield/plant (43.62 and $48.24 \mathrm{~g}$ ), lint cotton yield/plant (16.60 and $17.98 \mathrm{~g})$, boll weight (2.954 and $3.101 \mathrm{~g}$ ), lint percentage (37.89 and $37.21 \%)$, lint index $(6.245$ 
and $6.112 \mathrm{~g}$ ), seed cotton yield/fed (7.84 and 8.67 kentar) in addition to lint cotton yield/fed (9.39 and 10.17 kentar) were obtained from cotton sowing under fertilized by $50 \% \mathrm{~A}$ and foliar spray of compost tea in both seasons, respectively. While, Cotton plants treated with $100 \%$ mineral fertilizer treatment markedly recorded the lowest mean values of No. of opened bolls/plant (13.97 and 15.20) and opened bolls percentage (53.95 and $56.65 \%$ ) in both seasons, respectively. The superiority ratios in 2019 season between application $75 \% \mathrm{~A}$ and foliar spray of compost tea with algae extracts treatment and each of $100 \%$ mineral fertilizer (A), $50 \% \mathrm{~A}$ and foliar spray of compost tea extract, $50 \% \mathrm{~A}$ and foliar spray of algae extract, $50 \% \mathrm{~A}$ and foliar spray of compost tea with algae extracts, $75 \% \mathrm{~A}$ and foliar spray of compost tea extract and $75 \%$ A with foliar spray of algae extract were 45.10, 38.17, 31.20, 23.98, 14.65 and $9.98 \%$ for No. of opened bolls/plant; 53.90, $60.71,48.02,37.80,19.16$ and $13.38 \%$ for seed cotton yield/plant; 59.82, 71.08, 55.87, 44.02, 21.26 and $14.47 \%$ for lint cotton yield/plant; 5.94, 16.45, 13.01, 11.04, 4.05 and $2.99 \%$ for boll weight; 53.48, $60.33,48.23,37.98,19.26$ and $13.14 \%$ for seed cotton yield/fed in addition to $59.24,70.61,56.14$, 44.06, 21.36 and $14.18 \%$ for lint cotton yield/fed, respectively. The increase ratios in 2020 season were 45.39, 42.49, 33.94, 25.85, 17.37 and $10.94 \%$ for No. of opened bolls/plant; 59.60, 66.42, 51.44, 38.56, 24.85 and $14.10 \%$ for seed cotton yield/plant; 66.87 , $78.75,61.43,47.09,27.24$ and $14.91 \%$ for lint cotton yield/plant; 9.59, 16.48, 12.80, 10.02, 6.55 and 2.94 $\%$ for boll weight; 59.42, 65.86, 51.05, 38.54, 24.83 and $14.13 \%$ for seed cotton yield/fed in addition to 66.76, 78.07, 60.83, 47.00, 27.18 and $14.91 \%$ for lint cotton yield/fed when using the same treatments, respectively. The increase in seed cotton and lint cotton yield and its attributes by foliar spray of compost tea and algae extracts may be due to the role of algae extract in activating growth of plants due to contains high levels of organic matter, micro elements, vitamins and amino acids and also, rich in growth regulators such as auxins, cytokinin and gibberellins (Table 3) in addition to compost tea comprised of a large and diverse community of microbes, humic acids and other chemical nutrients such as carbon and nitrogen that support healthy plant growth (Table 4). It was clear that the increase in seed and lint cotton yield/fed may be due to the increases in mean values of plant height, No. of sympodial/plant, No. of fruiting sites/plant, No. of opened bolls/plant, No. of total bolls/plant, opened bolls percentage, seed cotton yield/plant, lint cotton yield/plant, boll weight, lint percentage and lint index of cotton resulting from application of $75 \% \mathrm{~A}$ and foliar spray of compost tea with algae extracts treatment. These results are in compatible with those found by Babu et al. (2015); Zewail and Ahmed (2015); Gencsoylu (2016); Salama et al. (2018); Sultana et al. (2018); Abd El-Gayed et al. (2019);
Ahmed et al. (2020 b); Yanni et al. (2020) and Ahmed (2021).

\section{The interaction effect between Egyptian cotton varieties and natural extracts with mineral fertilization rates}

Results in Table 7 show that the interaction effect among Egyptian cotton varieties and fertilizer treatments induced significant differences on almost cotton growth, yield and its related traits except No. of monopodial/plant, No. of un-opened bolls/plant, seed index (g) and lint index (g) during 2019 and 2020 seasons. The highest mean values in No. of sympodial/plant (17.24 and 19.21), No. of fruiting sites/plant (46.59 and 51.22), No. of opened bolls/plant (21.98 and 23.88), No. of total bolls/plant (32.69 and 35.11), opened bolls percentage (67.24 and $68.01 \%)$, seed cotton yield/plant (80.42 and $92.37 \mathrm{~g})$, lint cotton yield/plant (33.14 and $37.76 \mathrm{~g})$, boll weight $(3.659$ and $3.868 \mathrm{~g})$, lint percentage (41.21 and $40.88 \%$ ), seed cotton yield/fed (13.78 and 15.81 kentar) and lint cotton yield/fed (17.89 and 20.36 kentar) in 2019 and 2020 seasons, respectively were recorded from growing promising cotton variety of Giza 97 treated by $75 \%$ A and foliar spray of compost tea with algae extracts treatment. On the other hand, planting Giza 94 variety treated by $50 \%$ A and foliar spray of compost tea gave the lowest mean values in No. of sympodial/plant (10.84 and 11.57), No. of fruiting sites/plant (32.59 and 34.67), No. of total bolls/plant (21.35 and 23.16), seed cotton yield/plant (35.89 and $42.25 \mathrm{~g}$ ), lint cotton yield/plant (13.28 and $15.54 \mathrm{~g}$ ), boll weight (2.784 and $2.986 \mathrm{~g}$ ), lint percentage (37.02 and $36.77 \%)$, seed cotton yield/fed (6.86 and 8.06 kentar) and lint cotton yield/fed (8.00 and 9.34 kentar) in 2019 and 2020 seasons respectively, meanwhile planting the same cotton variety under soil fertilized by $100 \%$ mineral fertilizer treatment gave the lowest mean values in No. of opened bolls/plant (12.57 and 13.85) and opened bolls percentage (53.35 and $56.46 \%$ ) during both seasons, respectively. Plants of Giza 94 variety treated by $75 \%$ A and foliar spray of compost tea with algae extracts treatment recorded the highest mean values of plant height (156.74 and $162.73 \mathrm{~cm})$ in 2019 and 2020 seasons, respectively. On the other hand, the lowest mean values of plant height (132.24 and $130.42 \mathrm{~cm}$ ) in both seasons, respectively were obtained in Giza 97 variety with $50 \%$ A and foliar spray of compost tea. Sowing Giza 94 variety under soil fertilized by $100 \%$ mineral fertilizer treatment recorded the maximum mean values of bolls shedding percentage (35.54 and $36.42 \%$ ) in both seasons, respectively. On the other hand, the lowest mean values of bolls shedding percentage (22.45 and $28.04 \%$ ) in the respective two seasons was recorded in Giza 97 variety treated by $50 \% \mathrm{~A}$ and foliar spray of compost tea. The results reported here are in harmony with those obtained by Babu et al. 2015. 
Table 6. Mean values of vegetative growth, yield and yield components of Egyptian cotton as affected by natural extracts with mineral fertilization rates during 2019 and 2020 seasons

\begin{tabular}{|c|c|c|c|c|c|c|c|c|}
\hline \multirow{3}{*}{ Trait } & \multicolumn{8}{|c|}{ Natural extracts with mineral fertilization rates } \\
\hline & $\mathbf{A}$ & B & $\mathbf{C}$ & D & $\mathbf{E}$ & $\mathbf{F}$ & $\mathbf{G}$ & $\begin{array}{l}\text { L.S.D. } \\
\text { at } 5 \%\end{array}$ \\
\hline & \multicolumn{8}{|c|}{ The 2019 season } \\
\hline Plant height (cm) & 142.71 & 145.42 & 148.46 & 151.09 & 138.80 & 140.91 & 141.81 & 5.76 \\
\hline No. of monopodial/plant & 2.455 & 2.575 & 2.695 & 2.775 & 2.175 & 2.265 & 2.350 & N.S. \\
\hline No. of sympodial/plant & 12.60 & 13.84 & 14.63 & 15.95 & 11.06 & 11.93 & 12.25 & 0.45 \\
\hline No. of fruiting sites/plant & 39.10 & 40.08 & 42.82 & 43.57 & 33.43 & 34.81 & 35.77 & 2.88 \\
\hline No. of opened bolls/plant & 13.97 & 17.68 & 18.43 & 20.27 & 14.67 & 15.45 & 16.35 & 1.43 \\
\hline No. of un-opened bolls/plant & 11.90 & 9.48 & 10.36 & 9.92 & 9.30 & 9.81 & 9.43 & N.S. \\
\hline No. of total bolls/plant & 25.86 & 27.16 & 28.79 & 30.19 & 23.96 & 25.25 & 25.78 & 2.12 \\
\hline Opened bolls percentage (\%) & 53.95 & 64.91 & 63.97 & 67.14 & 61.12 & 60.86 & 63.17 & 1.68 \\
\hline Bolls shedding percentage $(\%)$ & 33.96 & 32.38 & 32.85 & 30.79 & 28.47 & 27.58 & 28.03 & N.S. \\
\hline Seed cotton yield/plant (g) & 45.55 & 58.83 & 61.83 & 70.10 & 43.62 & 47.36 & 50.87 & 4.45 \\
\hline Lint cotton yield/plant (g) & 17.77 & 23.42 & 24.81 & 28.40 & 16.60 & 18.22 & 19.72 & 1.84 \\
\hline Boll weight (g) & 3.247 & 3.306 & 3.340 & 3.440 & 2.954 & 3.044 & 3.098 & 0.101 \\
\hline Seed index $(g)$ & 11.02 & 10.90 & 11.03 & 11.17 & 10.26 & 10.47 & 10.62 & N.S. \\
\hline Lint percentage $(\%)$ & 38.94 & 39.64 & 40.00 & 40.39 & 37.89 & 38.31 & 38.66 & 0.33 \\
\hline Lint index (g) & 7.019 & 7.138 & 7.337 & 7.548 & 6.245 & 6.484 & 6.680 & 0.124 \\
\hline Seed cotton yield/fed (kentar) & 8.19 & 10.54 & 11.11 & 12.57 & 7.84 & 8.48 & 9.11 & 1.02 \\
\hline \multirow[t]{2}{*}{ Lint cotton yield/fed (kentar) } & 10.06 & 13.20 & 14.03 & 16.02 & 9.39 & 10.26 & 11.12 & 1.34 \\
\hline & \multicolumn{8}{|c|}{ The 2020 season } \\
\hline Plant height (cm) & 147.48 & 149.62 & 152.33 & 155.85 & 139.57 & 142.60 & 145.79 & 6.62 \\
\hline No. of monopodial/plant & 2.595 & 2.680 & 2.800 & 2.890 & 2.365 & 2.945 & 2.555 & N.S. \\
\hline No. of sympodial/plant & 14.00 & 15.23 & 16.48 & 17.99 & 12.28 & 13.25 & 13.67 & 0.51 \\
\hline No. of fruiting sites/plant & 42.10 & 43.42 & 45.86 & 47.55 & 36.33 & 38.77 & 40.07 & 3.29 \\
\hline No. of opened bolls/plant & 15.20 & 18.83 & 19.92 & 22.10 & 15.51 & 16.50 & 17.56 & 1.57 \\
\hline No. of un-opened bolls/plant & 11.62 & 10.42 & 10.40 & 10.51 & 9.74 & 9.95 & 10.55 & N.S. \\
\hline No. of total bolls/plant & 26.82 & 29.25 & 30.32 & 32.61 & 25.25 & 26.45 & 28.11 & 2.34 \\
\hline Opened bolls percentage $(\%)$ & 56.65 & 64.36 & 65.71 & 67.75 & 61.41 & 62.26 & 62.36 & 1.79 \\
\hline Bolls shedding percentage $(\%)$ & 36.32 & 32.78 & 33.90 & 31.42 & 30.62 & 31.75 & 29.87 & N.S. \\
\hline Seed cotton yield/plant (g) & 50.30 & 64.30 & 70.36 & 80.28 & 48.24 & 53.01 & 57.94 & 4.95 \\
\hline Lint cotton yield/plant (g) & 19.26 & 25.26 & 27.97 & 32.14 & 17.98 & 19.91 & 21.85 & 2.12 \\
\hline Boll weight (g) & 3.296 & 3.390 & 3.509 & 3.612 & 3.101 & 3.202 & 3.283 & 0.114 \\
\hline Seed index $(g)$ & 11.32 & 11.12 & 11.27 & 11.43 & 10.33 & 10.61 & 10.75 & N.S. \\
\hline Lint percentage $(\%)$ & 38.18 & 39.11 & 39.60 & 39.88 & 37.21 & 37.50 & 37.62 & 0.41 \\
\hline Lint index (g) & 6.983 & 7.127 & 7.368 & 7.562 & 6.112 & 6.352 & 6.467 & 0.135 \\
\hline Seed cotton yield/fed (kentar) & 9.02 & 11.52 & 12.60 & 14.38 & 8.67 & 9.52 & 10.38 & 1.17 \\
\hline Lint cotton yield/fed (kentar) & 10.86 & 14.24 & 15.76 & 18.11 & 10.17 & 11.26 & 12.32 & 1.49 \\
\hline
\end{tabular}

Where, $\mathbf{A}=$ control (full dose of mineral fertilization rates with $60 \mathrm{~kg} \mathrm{~N}, 30 \mathrm{Kg} \mathrm{P}_{2} \mathrm{O}_{5}$ and $48 \mathrm{~kg} \mathrm{~K} 2 \mathrm{O} / \mathrm{fed}$ ), $\mathbf{B}=75 \% \mathrm{~A}$ and foliar spray of compost tea, $\mathbf{C}=75 \% \mathrm{~A}$ and foliar spray of algae extract, $\mathbf{D}=75 \% \mathrm{~A}$ and foliar spray of compost tea and algae extract, $\mathbf{E}=50 \% \mathrm{~A}$ and foliar spray of compost tea, $\mathbf{F}=50 \% \mathrm{~A}$ and foliar spray of algae extract and $\mathbf{G}=50 \% \mathrm{~A}$ and foliar spray of compost tea and algae extract. 
Table 7. Mean values of vegetative growth, yield and yield components as affected by the interaction between Egyptian cotton varieties and natural extracts with mineral fertilization rates during 2019 and 2020 seasons

\begin{tabular}{|c|c|c|c|c|c|c|c|c|c|c|c|c|c|}
\hline \multirow{2}{*}{\multicolumn{2}{|c|}{$\begin{array}{c}\text { Trait } \\
\text { Treatment }\end{array}$}} & \multicolumn{2}{|c|}{ Plant height (cm) } & \multicolumn{2}{|c|}{$\begin{array}{c}\text { No. of } \\
\text { monopodial/plant }\end{array}$} & \multicolumn{2}{|c|}{$\begin{array}{c}\text { No. of } \\
\text { sympodial/plant }\end{array}$} & \multicolumn{2}{|c|}{$\begin{array}{c}\text { No. of fruiting } \\
\text { sites/plant }\end{array}$} & \multicolumn{2}{|c|}{$\begin{array}{c}\text { No. of opened } \\
\text { bolls/plant }\end{array}$} & \multicolumn{2}{|c|}{$\begin{array}{c}\text { No. of un-opened } \\
\text { bolls/plant }\end{array}$} \\
\hline & & 2019 & 2020 & 2019 & 2020 & 2019 & 2020 & 2019 & 2020 & 2019 & 2020 & 2019 & 2020 \\
\hline \multirow{7}{*}{$\begin{array}{c}\text { Giza } \\
94\end{array}$} & $\mathbf{A}$ & 149.23 & 155.43 & 2.960 & 3.060 & 11.56 & 12.34 & 36.55 & 38.58 & 12.57 & 13.85 & 10.99 & 10.68 \\
\hline & B & 150.47 & 155.67 & 3.050 & 3.110 & 12.78 & 13.98 & 37.50 & 39.85 & 15.47 & 16.73 & 9.06 & 9.38 \\
\hline & C & 154.35 & 158.79 & 3.110 & 3.260 & 13.57 & 15.11 & 39.87 & 41.98 & 16.74 & 18.27 & 9.61 & 9.44 \\
\hline & D & 156.74 & 162.73 & 3.240 & 3.340 & 14.65 & 16.76 & 40.55 & 43.88 & 18.56 & 20.32 & 9.12 & 9.79 \\
\hline & $\mathbf{E}$ & 145.36 & 148.71 & 2.560 & 2.840 & 10.84 & 11.57 & 32.59 & 34.67 & 12.89 & 14.15 & 8.46 & 9.01 \\
\hline & $\mathbf{F}$ & 147.84 & 151.63 & 2.680 & 2.930 & 11.21 & 11.97 & 33.74 & 35.98 & 13.24 & 14.89 & 9.90 & 9.85 \\
\hline & G & 148.31 & 153.76 & 2.790 & 3.010 & 11.51 & 12.11 & 34.39 & 36.56 & 14.26 & 15.66 & 9.61 & 9.90 \\
\hline \multirow{7}{*}{$\begin{array}{c}\text { Giza } \\
97\end{array}$} & $\mathbf{A}$ & 136.18 & 139.53 & 1.950 & 2.130 & 13.63 & 15.66 & 41.65 & 45.62 & 15.36 & 16.54 & 12.80 & 12.56 \\
\hline & B & 140.37 & 143.56 & 2.100 & 2.250 & 14.89 & 16.47 & 42.65 & 46.98 & 19.88 & 20.93 & 9.90 & 11.45 \\
\hline & $\mathbf{C}$ & 142.57 & 145.87 & 2.280 & 2.340 & 15.68 & 17.85 & 45.77 & 49.74 & 20.11 & 21.56 & 11.11 & 11.36 \\
\hline & D & 145.43 & 148.97 & 2.310 & 2.440 & 17.24 & 19.21 & 46.59 & 51.22 & 21.98 & 23.88 & 10.71 & 11.23 \\
\hline & $\mathbf{E}$ & 132.24 & 130.42 & 1.790 & 1.890 & 11.27 & 12.98 & 34.26 & 37.98 & 16.44 & 16.87 & 10.13 & 10.46 \\
\hline & $\mathbf{F}$ & 133.98 & 133.57 & 1.850 & 2.960 & 12.65 & 14.52 & 35.88 & 41.56 & 17.65 & 18.11 & 9.71 & 10.04 \\
\hline & G & 135.31 & 137.82 & 1.910 & 2.100 & 12.98 & 15.23 & 37.15 & 43.57 & 18.44 & 19.45 & 9.25 & 11.20 \\
\hline \multicolumn{2}{|c|}{ L.S.D. at 5\% } & 8.15 & 9.36 & N.S. & N.S. & 0.64 & 0.72 & 4.07 & 4.65 & 2.02 & 2.22 & N.S. & N.S. \\
\hline \multicolumn{2}{|c|}{ Trait } & \multicolumn{2}{|c|}{$\begin{array}{l}\text { No. of total } \\
\text { bolls/plant }\end{array}$} & \multicolumn{3}{|c|}{ Opened bolls \% } & Bolls sh & ding \% & \multicolumn{3}{|c|}{$\begin{array}{c}\text { Seed cotton } \\
\text { yield/plant (g) }\end{array}$} & \multicolumn{2}{|c|}{$\begin{array}{c}\text { Lint cotton } \\
\text { yield/plant (g) }\end{array}$} \\
\hline \multicolumn{2}{|c|}{ Treatment } & 2019 & 2020 & \multicolumn{2}{|c|}{2019} & 2020 & 2019 & 2020 & 2019 & & & 2019 & 2020 \\
\hline & $\mathbf{A}$ & 23.56 & 24.53 & & & 56.46 & 35.54 & 36.42 & 38.90 & & & 14.93 & 16.18 \\
\hline & B & 24.53 & 26.11 & & & 64.08 & 34.59 & 34.48 & 48.33 & & & 18.69 & 20.21 \\
\hline & $\mathbf{C}$ & 26.35 & 27.71 & & & 65.93 & 33.91 & 33.99 & 53.03 & & & 20.75 & 22.74 \\
\hline 94 & D & 27.68 & 30.11 & & & 67.49 & 31.74 & 31.38 & 59.78 & & & 23.65 & 26.51 \\
\hline & $\mathbf{E}$ & 21.35 & 23.16 & & & 61.10 & 34.49 & 33.20 & 35.89 & & & 13.28 & 15.54 \\
\hline & $\mathbf{F}$ & 23.14 & 24.74 & & & 60.19 & 31.42 & 31.24 & 38.25 & & & 14.35 & 17.01 \\
\hline & G & 23.87 & 25.56 & & & 61.27 & 30.59 & 30.09 & 42.71 & & & 16.22 & 18.05 \\
\hline & $\mathbf{A}$ & 28.16 & 29.10 & & & 56.84 & 32.39 & 36.21 & 52.19 & & & 20.62 & 22.35 \\
\hline & B & 29.78 & 32.38 & & & 64.64 & 30.18 & 31.08 & 69.34 & & & 28.15 & 30.31 \\
\hline & C & 31.22 & 32.92 & & & 65.49 & 31.79 & 33.82 & 70.63 & & & 28.86 & 33.20 \\
\hline $\begin{array}{c}\text { Giza } \\
97\end{array}$ & D & 32.69 & 35.11 & & & 68.01 & 29.83 & 31.45 & 80.42 & & & 33.14 & 37.76 \\
\hline & $\mathbf{E}$ & 26.57 & 27.33 & & & 61.73 & 22.45 & 28.04 & 51.36 & & & 19.91 & 20.42 \\
\hline & $\mathbf{F}$ & 27.36 & 28.15 & & & 64.33 & 23.75 & 32.27 & 56.46 & & & 22.08 & 22.81 \\
\hline & $\mathbf{G}$ & 27.69 & 30.65 & & & 63.46 & 25.46 & 29.65 & 59.03 & & & 23.22 & 25.65 \\
\hline L.S.I & $5 \%$ & 3.00 & 3.31 & & & 2.53 & 2.70 & 3.07 & 6.29 & & & 2.60 & 3.00 \\
\hline & & Boll w & ht (g) & Seed & ex (g) & Liı & & Lint is & ex (g) & $\begin{array}{r}\text { Seed } \\
\text { yield/fe } \\
\end{array}$ & $\begin{array}{l}\text { tton } \\
\text { kentar) }\end{array}$ & $\begin{array}{r}\text { Lint } \\
\text { yield/fe }\end{array}$ & $\begin{array}{l}\text { otton } \\
\text { (kentar) }\end{array}$ \\
\hline Tre & ient & 2019 & 2020 & 2019 & 2020 & 2019 & 2020 & 2019 & 2020 & 2019 & 2020 & 2019 & 2020 \\
\hline & $\mathbf{A}$ & 3.095 & 3.136 & 11.51 & 11.65 & 38.37 & 37.25 & 7.166 & 6.916 & 7.43 & 8.25 & 8.98 & 9.69 \\
\hline & B & 3.124 & 3.169 & 11.67 & 11.89 & 38.68 & 38.12 & 7.361 & 7.325 & 9.21 & 10.10 & 11.22 & 12.12 \\
\hline & C & 3.168 & 3.221 & 11.81 & 12.04 & 39.12 & 38.64 & 7.589 & 7.582 & 10.10 & 11.17 & 12.44 & 13.60 \\
\hline $\begin{array}{c}\text { Giza } \\
94\end{array}$ & D & 3.221 & 3.356 & 11.98 & 12.23 & 39.56 & 38.88 & 7.841 & 7.780 & 11.37 & 12.95 & 14.16 & 15.86 \\
\hline & $\mathbf{E}$ & 2.784 & 2.986 & 11.02 & 10.98 & 37.02 & 36.77 & 6.478 & 6.385 & 6.86 & 8.06 & 8.00 & 9.34 \\
\hline & $\mathbf{F}$ & 2.889 & 3.089 & 11.32 & 11.45 & 37.51 & 36.98 & 6.795 & 6.719 & 7.30 & 8.76 & 8.63 & 10.21 \\
\hline & G & 2.995 & 3.114 & 11.49 & 11.57 & 37.98 & 37.01 & 7.036 & 6.798 & 8.13 & 9.27 & 9.72 & 10.81 \\
\hline & $\mathbf{A}$ & 3.398 & 3.456 & 10.52 & 10.98 & 39.51 & 39.1 & 6.871 & 7.050 & 8.95 & 9.78 & 11.14 & 12.04 \\
\hline & B & 3.488 & 3.611 & 10.12 & 10.35 & 40.59 & 40.1 & 6.914 & 6.929 & 11.87 & 12.95 & 15.18 & 16.36 \\
\hline & C & 3.512 & 3.797 & 10.25 & 10.49 & 40.87 & 40.55 & 7.085 & 7.155 & 12.13 & 14.03 & 15.61 & 17.92 \\
\hline $\begin{array}{c}\text { Giza } \\
97\end{array}$ & D & 3.659 & 3.868 & 10.35 & 10.62 & 41.21 & 40.88 & 7.255 & 7.343 & 13.78 & 15.81 & 17.89 & 20.36 \\
\hline & $\mathbf{E}$ & 3.124 & 3.215 & 9.5 & 9.67 & 38.76 & 37.65 & 6.013 & 5.839 & 8.83 & 9.27 & 10.78 & 10.99 \\
\hline & $\mathbf{F}$ & 3.199 & 3.314 & 9.61 & 9.76 & 39.11 & 38.01 & 6.173 & 5.984 & 9.65 & 10.29 & 11.89 & 12.32 \\
\hline & $\mathbf{G}$ & 3.201 & 3.451 & 9.75 & 9.92 & 39.34 & 38.22 & 6.323 & 6.137 & 10.10 & 11.49 & 12.51 & 13.84 \\
\hline L.S. & $5 \%$ & 0.143 & 0.161 & N.S. & N.S. & 0.47 & 0.58 & N.S. & N.S. & 1.44 & 1.65 & 1.90 & 2.11 \\
\hline
\end{tabular}

Where, $\mathbf{A}=$ control (full dose of mineral fertilization rates with $60 \mathrm{~kg} \mathrm{~N}, 30 \mathrm{Kg} \mathrm{P}_{2} \mathrm{O}_{5}$ and $48 \mathrm{~kg} \mathrm{~K} 2 \mathrm{O} / \mathrm{fed}$ ), $\mathbf{B}=75 \% \mathrm{~A}$ and foliar spray of compost tea, $\mathbf{C}=75 \%$ A and foliar spray of algae extract, $\mathbf{D}=75 \%$ A and foliar spray of compost tea with algae extracts, $\mathbf{E}=50 \% \mathrm{~A}$ and foliar spray of compost tea, $\mathbf{F}=50 \% \mathrm{~A}$ and foliar spray of algae extract and $\mathbf{G}=50$ $\% \mathrm{~A}$ and foliar spray of compost tea with algae extracts. 


\section{Conclusion}

Based on the previous results it could be concluded that, growing promising cotton variety of Giza 97 treated by $75 \%$ A and foliar spray with the compost tea along with algae extract treatment produced the maximum seed cotton yield and its related traits.

\section{References}

Abd El-Aal, M. M. M. (2012). Response of Ananas melon plants to foliar spray with some natural extracts. Res. J. Agric. \& Biol. Sci., 8 (2): 201212.

Abd El-Gayed, S. SH.; S. G. Gebaly and M. A. A. Ibrahim (2019). Effect of some bio-stimulates (azola, PGPR, and compost tea) on growth, yield and its components, fiber properties and leaves constituents of cotton plant. Egypt. J. of Appl. Sci., 34 (7): 142-151.

Abdallah, A. M. and H. F. Y. Mohamed (2013). Effect of foliar application of some micronutrients and growth regulators on some Egyptian cotton cultivars. J. Appl. Sci. Res., 9 (6): 3497-3507.

Ahmed, H. S. A. (2021). Effect of eco- friendly fertilizers on yield and fiber quality in Egyptian cotton. Middle East J. Appl. Sci., 11 (2): under press.

Ahmed, H. S. A.; M H. A. Hossein and W. M. B. Yehia (2020 a). Response of some Egyptian cotton varieties for biofertilizer and its effect on yield, yield components and fiber traits. Plant Archives, 20 (2): 9575-9583.

Ahmed, H. S. A.; M. H. A Hossein and H. S. A. ElDesoukey (2020 b). Effect of nano-fertilization and some bio-fertilizer on growth, yield and fiber quality of Egyptian cotton. Annals of Agric. Sci., Moshtohor, 58 (1): 35-44.

Alitabar, R. A.; R. Salimbeck; O. Alishah and S. A. Andarkhor (2012). Interactive effects of nitrogen and row spacing on growth and yield of cotton varieties. Int. J. Biol., 4 (3): 124-129.

Babu, S.; N. Bidyarani; P. Chopra; D. Monga; R. Kumar, R. Prasanna; S. Kranthi and A. K. Saxena (2015). Evaluating microbe-plant interactions and varietal differences for enhancing biocontrol efficacy in root rot disease challenged cotton crop. Eur. J. Plant Path., 142 (2): 345-362.

Begum, M.; B. C. Bordoloi; D. D. Singha and N. J. Ojha (2018). Role of seaweed extract on growth, yield and quality of some Agricultural crops: A review. Agricultural Reviews, 1-6.

Eef, B.; D. Marlies; K. Van-Swam; A. Veen and L. Burger (2018). Identification of the seaweed biostimulant market (Phase 1): The North Sea farm foundation: AD Den Haag, The Netherlands.

Elayan, S. E. D.; A. A. Abodahab; A. M. Abdallah and R. A. Houda (2014). Effect of foliar application of manganese and iron on growth characters, yield and fiber properties of some Egyptian cotton cultivars (Gossypium barbadense, L.). Intl. J. Agric. Crop Sci., 7 (13): 1283-1292.

Elayan, S. E. D.; A. M. A. Abdalla; N. S. D. AbdelGawad and W. A. E. Faramawy (2015). Effect of delaying planting date on yield, fiber and yarn quality properties in some cultivars and promising crosses of Egyptian cotton. Am-Euras. J. Agric. \& Env. Sci., 15 (5): 754-763.

El-Boukhari, M. E.; M. Barakate; Y. Bouhia and K. Lyamlouli (2020). Trends in seaweed extract based biostimulants: manufacturing process and beneficial effect on soil-plant systems. Plants, 9 (359): 1-23.

El-Gedwy, E. M. M.; A. E. M. Gadallh and R. M. Abdel-Twab (2018). Response of some Egyptian cotton cultivars to foliar spray by some microelements. Annals of Agric. Sci. Moshtohor, 56 (4): 965-974.

Freed, A. (1991). MSTATC microcomputer statistical program. Michigan State University, East Lansing, Michigan, USA.

Gencsoylu, I. (2016). Effect of seaweeds and organic foliar fertilizers on the cotton pests, predators, yield and fiber quality in cotton. J. Adnan Menderes Univ. Agric. Fac., 13 (2): 33-38.

Gomez, K. A. and A. A. Gomez (1984). Statistical procedures for agricultural research. 2nd, (ed). John Wiley and Sons, NY, USA.

Haas, D. and G. Défago (2005). Biological control of soil-borne pathogens by fluorescent pseudomonads-Nat. Rev. Microb.

Jamro, S. A.; A. N. Shah; M. I. Ahmad; G. M. Jamro; A. Khan; W. A. Siddique; A. Sher and G. A. Bugti (2016). Growth and yield response of cotton varieties under different methods of fertilizer application. J. Biodi. Env. Sci., 9 (4): 198-206.

Kassambara, E.M.; S. Sissoko; M. O. Diawara; N. Teme and A. A. Yattara (2019). Planting date effect on yield and fiber properties in some cultivars and promising crosses of cotton (Gossypium Hirsutum L.) in Mali. J. Bioanal. Biostat., 2 (1): 1-7.

Kumbhar, B. A.; S. A. Kumbhar and A. M. Kumbhar (2015). Quantitative and qualitative traits of cotton (Gossypium hirsutum) cultivars under fertility regimes. Agric. Sci. Res. J., 5 (12): 180-186.

Mahdy, E. E.; A. Abo-Elwafa; G. H. Abd ElZaher; M. A. Sayed and M. G. Hosein (2017). Tolerance of Egyptian cotton varieties (G. barbadense, L.) to late planting. Assiut J. Agric. Sci., 48 (3): 34-53.

Mahmoud, M. A.; A. A. El-Hendawy and M. Y. Awad (2016). Water productivity of some cotton varieties and yield under different irrigation methods. Assiut J. Agric. Sci., 47 (6-1): 203-216.

Rowell, D. L. (1995). Soil science methods and applications. Library of Congress Cataloging Publication Data. New York. NY 10158. USA. 
Salama, A. M.; S. A. F. Hamoda and A. E. Ghoniem (2018). Enhancement of cotton plant performance by nutrients under salinity stress. Biosci. Res., 15 (1): 133-144.

Scheuerell, S. J. and W. F. Mahaffee (2002). Compost tea principals and prospects for plant disease control. Compost Sci. Util., 10 (4): 313-338.

Sultana, V.; S. Tariq; K. Hira; A. Tariq; J. Ara; R. M. Tariq and S. Ehteshamul-Haque (2018). Seaweed bio-fertilizer for the management of root rotting fungi and root knot nematodes affecting cotton crop. Pak. J. Bot., 50 (6): 2409-2412.

The Egyptian Cotton Gazette (2021). Alcotexa, 154.

Wen, Y.; D. L. Rowland; G. Piccinni; J. T. Cothren; D. I. Leskovar; A. R. Kemanian and
J. D. Woodard (2013). Lint yield, lint quality, and economic returns of cotton production under traditional and regulated deficit irrigation schemes in southwest Texas. J. Cotton Sci., 17:10-22.

Yanni, Y. G.; A. A. Elashmouny and A. Y. Elsadany (2020). Differential response of cotton growth, yield and fiber quality to foliar application of Spirulina platensis and urea fertilizer. Asian J. Adv. Agric. Res., 12(1): 29-40.

Zewail, R. M. Y. and H. S. A. Ahmed (2015). Effect of some biofertilizers (PGPR, biosoal and compost tea) on growth, yield, fiber quality and yarn properties of Egyptian cotton (promising hybrid 10229xG86). Annals of Agric. Sci. Moshtohor, 53 (2): 199-210. 


\section{تأثير بعض المستخلصات الطبيعية بالتعاون مع الأسمدة المعدنية على نمو ومحصول بعض أصناف القطن المصري

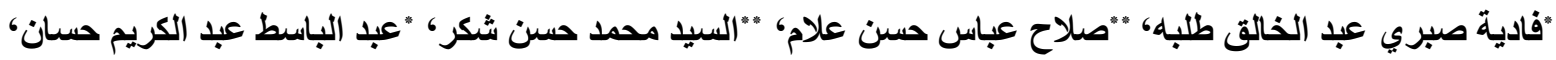

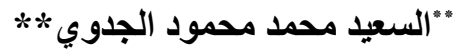

"معهد بحوث القطن ـ مركز البحوث الزراعية ـ الجيزة ـ مصر .

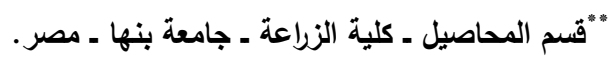

إجريت نجربة حقلية في محطة البحوث الزراعية بسا (محافظة كفر الثيخ) ـ معهد بحوث القطن ـ مركز البحوث الزراعية ـ جيزة . كصر " خلال الموسمين 2019 و2020 لدراسة تأثير التفاعل بين الرش الورقي بالمستخلصات الطبيعية والأسمدة المعدنية وكانت المعاملات

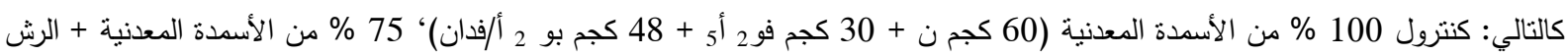
بمستخلص شاي الكمبوست، 75 \% من الأسمدة المعنية + الرش بمستخلص الطحالب، 75 \% من الأسمدة المعدنية + الرش بمستخلص شاي

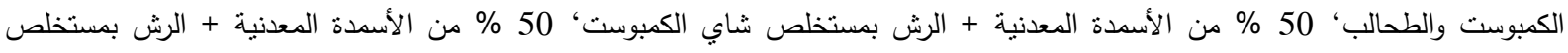
الطحالب و 50 \% من الأسمدة المعدنية + الرش بمستخلص شاي الكمبوست والطحالب على صفات النمو والمحصول ومكوناته لصنفان من القطن المصري جيزة 94 و جيزة 97. وكان التصميم التجريبي المستخدم هو القطاعات الكاملة العشوائية في أربع مكررات. أشنارت النتائج أن زراعة صنف القطن المصري الجديد (جيزة 97) تفوق معنوياً على الصنف القديم (جيزة 94) في متوسط قيم صنات التهات

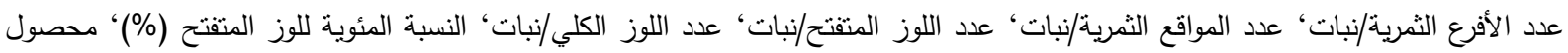

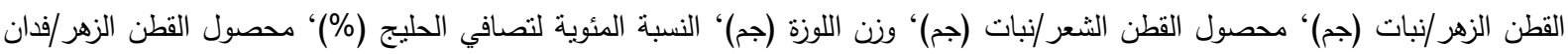

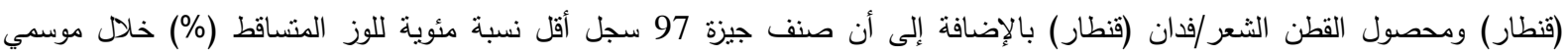

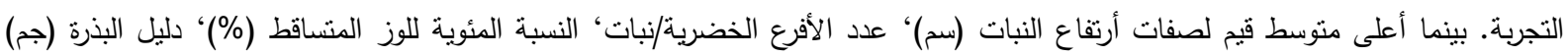
ودليل الشعر (جم) تم الحصول عليها من زراعة القطن المصري صنف جيزة 94 خلال موسمي الدراسة.

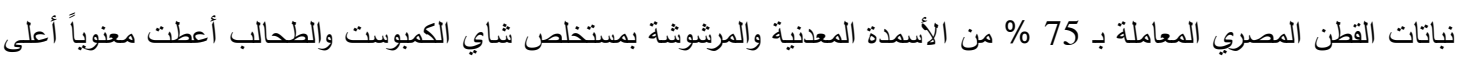

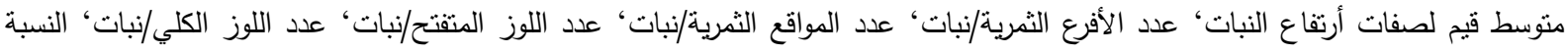

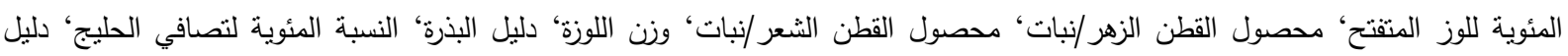

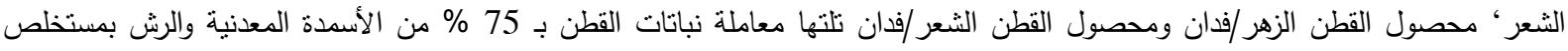

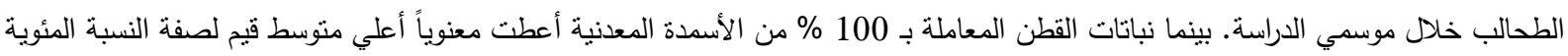
لللوز المتساقط بالإضافة إلى أقل منوسط قيم لصفتي عدد اللوز الكلي/نبات والنسبة المئوية للوز المتفتح خلال موسمي الدراسة.

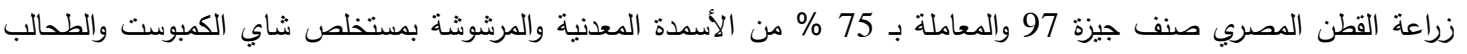

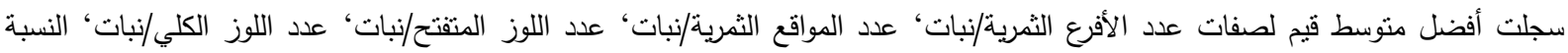

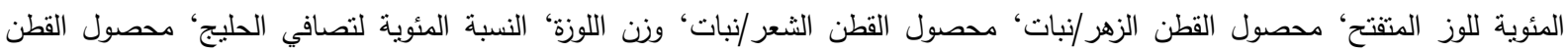

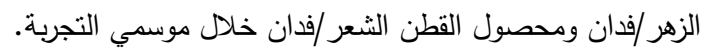
توصي النتائج بزراعة صنف القطن المصري الجديد (جيزة 97) مع التسميد بمعدل 75 \% من الأسمدة المعدنية والرش بمستخلص شاي الكمبوست والطحالب حيث عظمت إنتاجية محصول القطن بوحدة المساحة. 